Reprod. Nutr. Develop., 1988, 28 (3 B), 781-784

\title{
Specific effects of low-frequency stimulation upon energy metabolism in tibialis anterior muscles of mouse, rat, guinea pig and rabbit
}

\author{
J.-A. SIMONEAU, D. PETTE ( $\left.{ }^{1}\right)$
}

Faculty of Biology, University of Konstanz, $D-7750$ Konstanz, West Germany

Summary. Tibialis anterior (TA) muscles of four small mammals were subjected to chronic nerve stimulation for 28 days $(10 \mathrm{~Hz}, 10$ hours per day). Total cellular activities of phosphofructokinase (PFK), hexokinase (HK), citrate synthase (CS), 3-hydroxy-acyl-CoA dehydrogenase (HADH) and 3-hydroxybutyrate dehydrogenase (HBDH) were measured in the stimulated and unstimulated contralateral muscles. Normal TA muscles displayed ranges of oxidative and glycolytic capacities with rabbit TA showing the lowest and mouse TA the highest oxidative capacity. Chronic stimulation was almost without effect in mouse TA. In all other species, glycolytic capacity was decreased and reference enzymes of aerobic-oxidative pathways were increased. Rabbit TA displayed the highest increment in oxidative capacity with approximately three-fold increases in $\mathrm{CS}$ and HADH and eleven-fold increases in HBDH. Different responses were also observed for HK. In some cases, the extent of adaptation appeared to be independent of the initial enzyme activity levels, while in other cases it appeared to follow an order which corresponded to the size of the animals. Thus, there exist species-specific ranges of adaptation and adaptive alterations in one species may not necessarily reflect the adaptive response of another species.

\section{Introduction.}

It has been previously shown that low-frequency nerve stimulation induces a thorough rearrangement of the enzyme activity pattern of energy metabolism in fast-twitch hindlimb muscles of the rabbit (Pette, 1984 ; Reichmann et al., 1985). To study the extent to which such changes also apply to fast-twitch muscles of other small mammals, TA muscles of mouse, rat, guinea pig and rabbit were subjected to $10 \mathrm{~Hz}$ nerve stimulation (10 h daily) during a period of 28 days. Changes in the enzyme activity pattern were evaluated from selected enzymes representing specific metabolic pathways. Total cellular activities of phosphofructokinase (PFK), hexokinase (HK), citrate synthase (CS), 3-hydroxyacyl-CoA

(') To whom correspondence should be addressed. 
dehydrogenase (HADH), and 3-hydroxybutyrate dehydrogenase (HBDH) were used as reference enzymes of glycolysis, glucose phosphorylation, citric acid cycle, fatty acid oxidation and ketone body utilization, respectively. Methods for implanting electrodes, chronic stimulation and for enzyme assays have previously been described (Reichmann et al., 1985).

\section{Results and Discussion.}

Unstimulated TA muscles of mouse, rat and guinea pig displayed similar PFK activities. According to this enzyme, the glycolytic capacity was twofold higher in rabbit TA than in the other species (tabl. 1). On the other hand, CS and HADH activities decreased in the order mouse $>$ guinea pig $>$ rat $>$ rabbit. The chosen reference enzyme for ketone body utilization, $\mathrm{HBDH}$, was extremely low in unstimulated TA muscles of rabbit, guinea pig and mouse and was almost undetectable in rat TA.

\section{TABLE 1}

Enzyme activities (U/g wet weight) in 28 day stimulated (s) and contralateral, unstimulated (c) tibialis anterior muscles of rabbit, rat, guinea pig and mouse. Except for PFK in mouse, mean values of stimulated muscles are significantly different $(p<0.05)$ from mean values of contralateral muscles. Values represent means \pm SEM from 2-4 stimulated and 5-16 control muscles.

\begin{tabular}{lccccc}
\hline & & Rabbit & Rat & Guinea Pig & Mouse \\
\hline \multirow{2}{*}{ HK } & c & $0.71 \pm 0.1$ & $1.21 \pm 0.1$ & $1.22 \pm 0.1$ & $4.00 \pm 0.3$ \\
& s & 6.03 & $4.52 \pm 0.8$ & 2.24 & 7.29 \\
\hline \multirow{2}{*}{ PFK } & c & $142.0 \pm 8.0$ & $67.0 \pm 5.0$ & $78.0 \pm 8.0$ & $72.0 \pm 6.0$ \\
\hline \multirow{2}{*}{ CS } & s & 82.0 & $42.0 \pm 2.0$ & 27.0 & 83.0 \\
\hline \multirow{2}{*}{ HADH } & c & $10.5 \pm 0.9$ & $18.0 \pm 0.8$ & $23.4 \pm 2.1$ & $36.0 \pm 1.5$ \\
\hline \multirow{2}{*}{ HBDH } & s & 32.0 & $44.9 \pm 5.9$ & 57.8 & 42.4 \\
& s & $9.1 \pm 0.7$ & $16.1 \pm 1.5$ & $22.1 \pm 1.9$ & $31.5 \pm 2.3$ \\
& c & 28.5 & $25.3 \pm 3.7$ & 32.0 & 49.1 \\
\hline
\end{tabular}

Chronic stimulation had no effect upon PFK activity in mouse TA. By contrast, the activity level of this enzyme decreased by $30-50 \%$ of the control values in the other species. The activitie $S$ of $C S$ increased about 1.5 -fold in mouse, 2.5-fold in guinea pig and rat, and 3-fold in rabbit TA. Although HADH activity followed the direction of the changes in CS activity, the magnitude (approximately 1.5 -fold) was lower in rat and guinea pig. The increases in $\mathrm{HK}$ activity followed a similar pattern with the highest increment (eight-fold) in rabbit and the lowest (1.8-fold) in guinea pig and mouse. Pronounced differences also existed in the response of HBDH which increased eleven-fold in rabbit and rat, but only 5 -fold in guinea pig and 1.3-fold in mouse TA.

The present results are consistent with the previously established response of fast-twitch muscles of the rabbit to chronic stimulation (Pette et al., 1973, 1976 ; 
Heilig and Pette, 1980 ; Pette, 1984 ; Reichmann et al., 1985 ; Seedorf et al., 1986). However, the extent of change, especially the increase in mitochondrial enzyme activities, is lower than reported for the superficial part of stimulated TA muscle in the study of Reichmann et al. (1985). This discrepancy is most likely due to the fact that enzymes were extracted from whole muscle homogenates in the present study. In addition, stimulation lasted for only 10 hours/day as compared with 12 hours/day.

Our present results demonstrate that homologous muscles in small mammals do not respond uniformly when exposed to equal amounts of increased contractile activity. In some cases, the extent of adaptation was independent of the initial enzyme activity level, which may indicate the existence of different thresholds with regard to activity-induced changes. In other cases, such as the increases in mitochondrial enzymes of aerobic substrate oxidation (the citric acid cycle, fatty acid and ketone body oxidation), it appeared to follow an order which corresponded to the size of the animals. Thus, the increases were lowest in mouse and highest in rabbit. This may be related to the fact that TA muscles of the smaller mammals a priori display higher aerobic oxidative capacities than TA muscles of the larger mammals under study (tabl. 1). Hoppeler and Lindstedt (1985) have shown that skeletal muscles of small mammals are well endowed for aerobic substrate utilization. Increased contractile activity appears to represent a smaller stimulus to elicit adaptation of the aerobic substrate oxidation capacity in muscles of small mammals and, therefore, the response is more pronounced in larger mammals which, under normal conditions, base their muscle energy supply predominantly on anaerobic substrate utilization.

In conclusion, the present observations illustrate that the degree of metabolic adaptations to chronic stimulation is species-specific. Therefore, adaptive alterations in the enzyme activity pattern of skeletal muscle in one species may not necessarily reflect the adaptive response of another species.

$13^{e}$ Réunion du groupe Développement I.N.R.A. Cap d'Adge, 25-27 mai 1987.

Acknowledgements. - This study was supported by Deutsche Forschungsgemeinschaft, Sonderforschungsbereich 156. J.A.S. is a post-doctoral fellow of « Fonds de la Recherche en Santé du Québec, Canada».

Rèsumè. Effets spécifiques de la stimulation à faible fréquence sur le métabolisme énergétique des muscles tibialis antérieurs de la souris, du rat, du cochon d'Inde et du lapin.

Les muscles tibialis antérieurs (TA) de 4 petits mammifères furent soumis à une stimulation chronique via le nerf moteur pendant 28 jours $(10 \mathrm{~Hz}, 10$ heures par jour). L'activité des enzymes phosphofructokinase (PFK), hexokinase (HK), citrate synthase (CS), 3-hydroxyacyl CoA déshydrogénase (HADH) et 3-hydroxybutyrate déshydrogénase (HBDH) fut mesurée chez les muscles stimulés et contralatéraux non-stimulés. Les capacités glycolytique et aérobique oxydative des muscles TA non-stimulés des différentes espèces furent variées et ce furent les muscles TA du lapin et de la souris qui 
démontrèrent la plus faible et la plus élevée des capacités oxydatives, respectivement. La stimulation chronique du muscle TA de la souris fut pratiquement sans effet. Chez les autres espèces, la capacité glycolytique fut diminuée et l'activité des enzymes représentatifs des sentiers métaboliques oxydatifs fut augmentée. L'augmentation de la capacité oxydative fut la plus élevée chez le muscle TA du lapin avec des valeurs environ trois fois supérieures pour les enzymes CS et HADH et onze fois supérieures pour l'enzyme HBDH par rapport aux valeurs contrôles. Différentes réponses furent également notées au niveau de l'activité de l'enzyme HK. Dans plusieurs cas, le degré d'adaptation fut indépendant des capacités métaboliques initiales alors que dans d'autres cas, il apparaissait suivre un ordre correspondant à la grosseur de l'animal. Ainsi, il existe une spécificité au niveau de la capacité d'adaptation du muscle squelettique de sorte que les modifications observées chez une espèce animale pourraient ne pas s'appliquer à une autre espèce.

\section{References}

HEILIG A., PETTE D., 1980. Changes induced in the enzyme activity pattern by electrical stimulation of fast-twitch muscle, 409-420. In PETTE D., Plasticity of muscle, W. de Gruyter, Berlin-New York.

HOPPELER H., LINDSTEDT S. L., 1985 . Malleability of skeletal muscle in overcoming limitations : structural elements. J. exp. Biol., 115, 355-364.

PETTE D., 1984. Activity-induced fast to slow transitions in mammalian muscle. Med. Sci. Sports Exerc., 16, 517-528.

PETTE D., MÜLLER W., LEISNER E., VRBOVA $G$., 1976. Time dependent effects on contractile properties, fibre population, myosin light chains and enzymes of energy metabolism in intermittently and continuously stimulated fast twitch muscle of the rabbit. Pf/ügers Arch., 364. 103-112.

PETTE D., SMITH M. E., STAUDTE H. W., VRBOVA G., 1973. Effects of long-term electrical stimulation on some contractile and metabolic characteristics of fast rabbit muscles. Pf/ügers Arch., 338, 257-272.

REICHMANN H., HOPPELER H., MATHIEU-COSTELLO O., von BERGEN F., PETTE D., 1985. Biochemical and ultrastructural changes of skeletal muscle mitochondria after chronic electrical stimulation in rabbits. Pflügers Arch., 404, 1-9.

SeEdorf U., Leberer E., KIRSChBAUM B. J., PETTE D., 1986. Neural control of gene expression in skeletal muscle. Effects of chronic stimulation upon lactate dehydrogenase isozymes and citrate synthase. Biochem. J., 239, 115-120. 